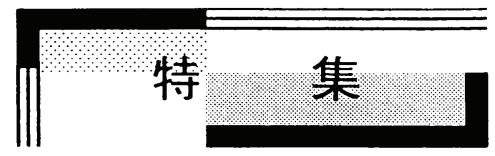

\title{
超音波スピニングレオメトリによる混相流体のレオロジ一試験*
}

\section{Rheometric Test for Multiphase Fluids by Means of Ultrasonic Spinning Rheometry}

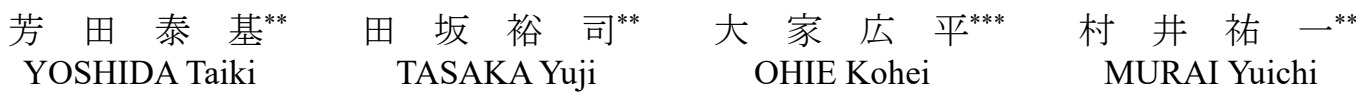

\begin{abstract}
For playing a role of filling a hole in the applicable range of standard rheometer, ultrasonic spinning rheometry (USR) is presented; it is based on equation of motion to explain the fluid rheology and to quantify the rheological properties satisfying the considered equation of motion for complex fluids. Some examples of rheological evaluation for multi-phase fluids using USR were presented; clay dispersion with thixotropy, polymer solution with large-spherical particles, dessert paste with pectin gel including fruit pulps. The efficacy of USR was discussed through those practical tests for complex fluid.
\end{abstract}

Keywords: Rheometry, Ultrasound, Clay dispersion, Polymer, Food rheology

\section{1. 緒 言}

多種多様な性質を持つ流動体が工業生産され る昨今、生産過程における流動は経験則により、 制御・管理・予測されている。レオロジー物性を 評価する計測機器（レオメータ）の信頼性がそし いために経験則に頼らざるを得ない現状がある。

産業・学理の多分野に最も広く利用される市販 レオメータの原型は、二百年以上前に完成されて おり、ラボレベルの分析に用いられるトルク式の 市販レオメータは、十二分に計測精度を有してい る。一方、計測確度の保証にはいくつかの仮定が 満たされる必要があるが、多くの非ニュートン性 流体ではそれが満たされないことが多い。測定対 象物質と回転子壁面との間での滑り [1]や、局所剪 断層 $[2,3]$ の発現、弾性的不安定性[4]など、「流動」 現象に由来する課題が数多く報告されている。市 販レオメータのユーザーの多くには認知されて おらず、レオメータにおける幾何設計固有のトル ク応答が評価されるため、計測結果の物理的な解 釈が難しくなる。

レオメータの表面性状[5]の改良や、クエット逆 問題に対する数学的な解法 [6]等、既存のレオメー
タの計測確度を改善する方法が数多く提案され ている中で、我々は流体挙動を直接計測し、物性 值の導出を試みる新たな手段に注目している。本 稿で紹介する超音波スピニングレオメトリ

（USR）[7-13]は、流動に仮定を与えず、流動を 計測することに基づいた手法である。先行研究と して、速度分布計測を用いるレオメトリ[14]があ り、計測をベースとする点で同一であるが、複雑 流体のダイナミクスに対し、運動方程式を満たす ようなレオロジー物性を逆算・定量化する点で異 なる。本稿では USR の概念とレオロジー物性を 評価する過程を解説する。さらに、USR に基づい た混相流体へのレオロジー評価例をいくつか紹 介し、評価結果に対して、流体工学的に基づいた 考察を与え、議論する。

\section{USR の計測概念}

\section{1 計測上の定義と基礎理論}

Fig. 1(a)が示すような半径 $R=72.5 \mathrm{~mm}$ のアク リル製円筒容器内に試験対象の流体を満たし、振 幅 $\Theta$ 、周波数 $f_{0}$ の正弦波振動を与える。この時、 円筒内部に伝播される運動量には、試験流体のレ

* 2020.4.10 受付

** 北海道大学 工学研究院 $\bar{T} 060-8628$ 札幌市北区北 13 条西 8 丁目

TEL: (011)706-6373 E-mail: yoshida@ring-me.eng.hokudai.ac.jp

*** 北海道大学大学院 工学院 $\bar{T} 060-8628$ 札幌市北区北 13 条西 8 丁目 
オロジー物性が反映される。超音波送受信器 （TDX）を介して受信されるドップラー信号（周 波数変調）から、超音波流速分布計測法 (UVP) により、計測線上の瞬時流速分布を取得する。周 方向流速が卓越している場合、計測方向流速成分 $u \xi$ は、 $u=u \xi r / \Delta y$ から周方向流速 $u$ として計算で きる。ここで、 $\Delta y$ は超音波計測線を円筒中心軸か らずらした距離である。

計測線上を伝播するディスク形状の超音波パ ルスは、Fig. 1(b)で図示されるような計測体積 $V$ を持つ。計測体積内の周方向流速 $u$ 、せん断応力 $\tau$ を

$$
\langle u\rangle \equiv \frac{1}{V} \int u d V,\langle\tau\rangle \equiv \frac{1}{V} \int \tau d V
$$

とそれぞれ定義できる。ここで、周方向一方向流 れ、かつ理想的な軸対称性が近似できる場合、角 運動量保存則から、支配方程式は、

$$
\frac{\partial(\rho\langle u\rangle r)}{\partial t}=\frac{1}{r} \frac{\partial\left(r^{2}\langle\tau\rangle\right)}{\partial r}, \text { s.t. } \tau=f(\dot{\gamma}, A, B, \mathrm{C}, \cdots)(2)
$$

と考えられる。ここで、関数 $f$ はせん断応力 $\langle\tau\rangle$ と流速変動 $\langle u\rangle$ の関係を記述する構成方程式で ある。以降、 $\langle\tau\rangle$ と $\langle u\rangle$ を $\tau$ と $u$ として、簡略化 して示す。 $A 、 B 、 C 、 \cdots は 、$ 構成方程式に含まれ る物性定数を示す。

数值流体力学 (CFD) では、これら物性定数を 運動方程式に与え、適切な境界条件の下で解くこ とで流速分布を得る。本稿で提案される USR で は、CFD とは逆のアプローチでレオロジー物性が 定量化される。つまり、UVPによって計測される 流速分布を拘束条件として、式(2)を満たすような 物性定数を評価する。ここで、最小二乗近似で記 述される費用関数、

$$
F_{\text {cost }}(A, B, C, \cdots)=\left(\rho \frac{\partial u}{\partial t}-\frac{\partial \tau}{\partial r}-\frac{2 \tau}{r}\right)^{2}
$$

を設定し、それが極小值を持つような未知数の組 み合わせを探索することで、物性定数は逆算され る[15]。後述の解析法は、この考えに基づいてい る。式(1)で定義したように、計測体積ごとに式(3) を満たすならば、局所半径位置毎に物性定数が評 価される。

\section{2 周波数空間における極小値探索}

ニュートンの粘性法則とフックの法則を組み 合わせた最も単純な粘弾性モデルの一つである、

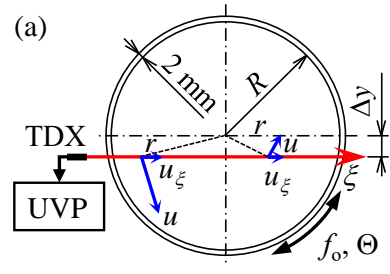

(b) Measurement volume $V$

Fig. 1 (a) Experimental setup, and (b) measurement line and volume of ultrasonic pulse beam.

マックスウェルモデル(バネーダンパ直列系) は、

$$
\tau+\frac{1}{\omega_{\mathrm{o}} \tan \delta} \frac{\partial \tau}{\partial t}=\mu\left(\frac{\partial u}{\partial r}-\frac{u}{r}\right)
$$

で記述される。 $\delta$ は粘性係数 $\mu$ と弾性係数 $E$ から、

$$
\tan \delta=\frac{E}{\omega_{0} \mu}
$$

と定義される。 $\delta$ の值は、 $\delta \approx \pi / 2 \mathrm{rad}$ ならば粘性 的、 $\delta \approx 0 \mathrm{rad}$ ならば弾性的、 $0<\delta<\pi / 2 \mathrm{rad}$ ならば 粘弾性的、のようにレオロジー的特徵を定量的に 示す。

式(4)のような構成方程式は、一般にレオロジー モデルと呼称される。多種多様に存在する流体の レオロジー的特徴を表現するために用いられる。 通常、市販レオメータで計測される情報から物性 值を評価する近似関数として用いられる。強調す べきは、USRにおける構成方程式の意味が流動自 体を表現するための関数であるという点である。

式(3)と式(4)を用いることで、USR による線形 粘弾性解析が可能となるが、流速は計測ノイズを 含む離散值である。それゆえ、直接代入による有 限差分計算はノイズを増幅し、方程式のバランス が維持されない。Tasaka et al.は、与えられる正弦 波振動流れが卓越した単一周波数成分を持つこ とを利用し、有限差分計算を回避できる費用関数 計算アルゴリズムを提案した[9]。式(3)と式(4)を 時間 $t$ に対しフーリエ変換すると、

$$
\begin{aligned}
& F_{\text {cost }}(\mu, E ; r)=\int_{r}\left|i \rho \omega_{0} \hat{u}-\frac{d \hat{\tau}}{d r}-\frac{2 \hat{\tau}}{r}\right|_{\omega=\omega_{o}}^{2} d r \\
& \text { s.t. } \hat{\tau}+i \frac{1}{\tan \delta} \hat{\tau}=\mu\left(\frac{d}{d r}-\frac{1}{r}\right) \hat{u}
\end{aligned}
$$

とそれぞれ記述できる。ここで「^」はフーリエ変 換した関数を示す。解析に関する詳細な式の導出 
(a)

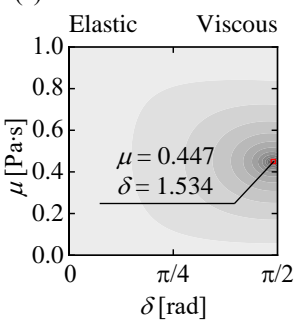

(b)

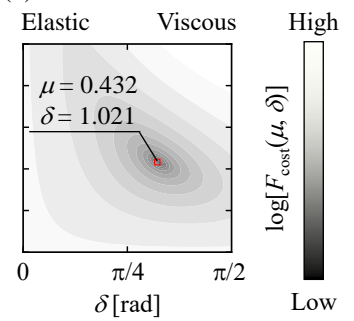

Fig. 2 Calculated results of $\mu-\delta$ contour in $F_{\text {cost }}$ at $r / R$ $\approx 0.9$; (a) silicon oil $\left(0.49\right.$ Pas at $\left.25^{\circ} \mathrm{C}\right)$, (b) CMC solution (0.5 wt.\%).

については、文献 $[9,11]$ 参照されたい。

典型的なニュートン流体であるシリコンオイ ルと擬塑性流体として知られるカルボキシメチ ルセルロース $(\mathrm{CMC})$ 水溶液を試験対象として、 計測した流速を式(6)と式(7)に代入し、それぞれ の費用関数值 $F_{\text {cost }}(\mu, \delta ; r / R=0.9)$ を定量化した

(Fig. 2)。等值線形状から、 $\mu-\delta$ 空間において、 $F_{\text {cost }}$ の值が唯一の極小点を持つ。各半径位置で、 極小点探索を行うことで、レオロジー物性の空間 分布を評価できる。定量化の精度を鑑みるに、実 用的には、極小点探索のための最適化計算アルゴ リズムの導入が必須である。

\section{3. 混相流体のレオロジー診断例}

ニュートン流体に対する USR の計測確度につ いては、すでに高い水準に至っているため、本稿 では省略し、主に市販レオメータ計測が困難とさ れる混相流体を対象にレオロジー診断例を示す。

\section{1 チキソトロピーを持つ粘土粒子懸濁液[11]}

多様に現存する粘土の中には、水中で電離・膨 潤し、クーロン力による粒子間結合からゲル化す るものがある。その性質を持つモンモリロナイト は厚さ $1 \mathrm{~nm}$ 程度、一辺が $0.1-10 \mu \mathrm{m}$ 程度の板状 の微粒子である。粒子間の結合力は弱く、剪断を 加えると容易にゾル化し、その状態で長時間静置 すると、結合が復活し再度ゲル化する。このよう な経時変化を伴う物性をチキソトロピー性とい う（Fig. 3）。固体的に振る舞うゲル相と、液体的 に振る舞うゾル相が共存し、経時的に変化するた め、市販レオメータでは計測が困難で、見かけの 粘性でしか評価できない [16]。

UVP によって計測された流速変動をフーリエ 変換し、振動周波数成分を取り出すと、一次元の

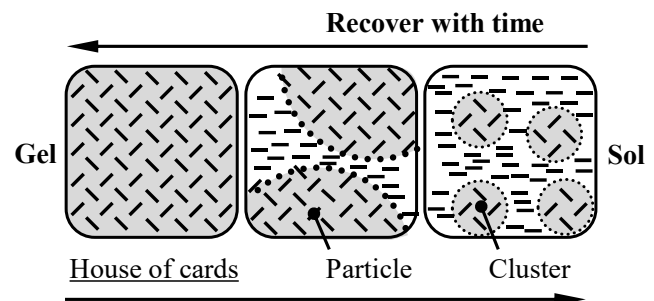

Shear deformation/flow

Fig. 3 Schematic of thixotropy mechanism of montmorillonite dispersion.

半径分布として流速変動の実部・虚部成分を定量 化できる（Fig. 4(a)）。流速変動の位相差は、

$$
\phi(r)=\tan ^{-1}\left(\frac{\mathfrak{J}\left[\hat{u}\left(r, \omega_{\mathrm{o}}\right)\right]}{\mathfrak{R}\left[\hat{u}\left(r, \omega_{\mathrm{o}}\right)\right]}\right)
$$

から計算することができる(Fig. 4(a))。ここで位 相差の半径方向勾配は、試験流体の流動性を示し ている[8,10,13]。つまり、位相差が勾配を持って いる場合、流体は振動に対し、追従的に変形・流 動する。一方で、位相差が一定の場合、流体は振 動に対して変形・流動していないことがわかる。 周方向の流速変動から流体の変形・流動度合いを 可視化（Fig. 4(b)）し、位相差とそれぞれ比較す ると、双方から同様な変形傾向が確認できる。ゆ えに、計測対象の粘土懸濁液には、振動に対して 変形・流動しないゲルの領域と変形・流動するゾ ルの領域が存在し、フーリエ成分はそれを反映す る。

上記、流速変動から計算される位相差は、振動 周期 $t f_{0} \approx 1500$ において計測された結果であるが、 チキソトロピー性をもつ粘土懸濁液は、経時的に 流動性が変化する。一度、円筒内の䀣濁液を攪拌 した後、 $f_{\mathrm{o}}=1.0 \mathrm{~Hz} 、 \Theta=4 \pi / 9 \mathrm{rad}$ で $10^{4} \mathrm{~s}$ 間 $\left(10^{4}\right.$ 周期分の振動）を加え、経時的なレオロジー物性 の変化を評価した。式(5)から計算される $\delta$ を、時 間とせん断ひずみ速度における等值線として、

Fig. 4(c)に示す。解析を施した流速分布の半径領 域は、 $0.5<r / R<0.9$ である。式( 8$)$ で与えられる、 位相差の半径勾配に閾值を与えることで、流体が ゲル状態であるか、否かおよそ定量的に判断でき る。ここで Fig. 4(c)の等值線において、斜線網掛 けされている部分は、ゲル状態として判断された 領域である。 $t=10^{4} \mathrm{~s}$ の $10^{0}<\dot{\gamma}_{\mathrm{eff}}<10^{1} \mathrm{~s}^{-1}$ の範囲

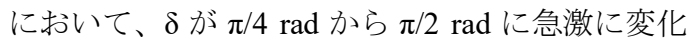




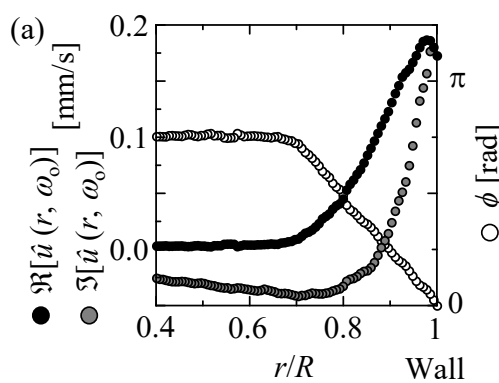

(b)

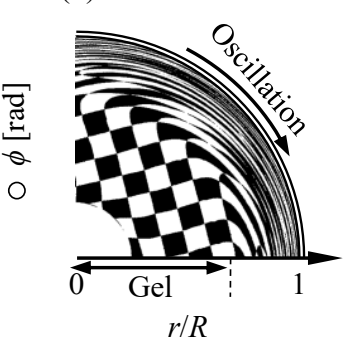

(c)

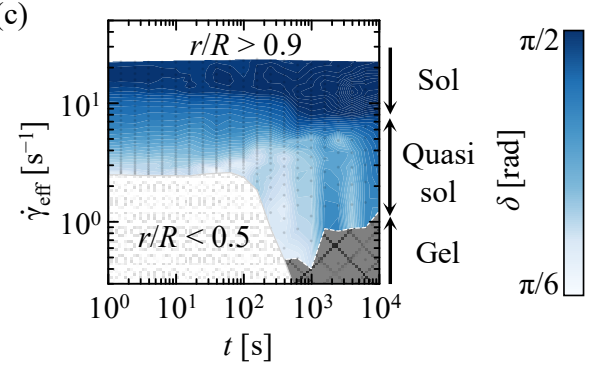

Fig. 4 (a) Real and imaginary parts of Fourier transformed velocity profile, and phase lag profile calculated by the Fourier transformed components, (b) flow visualization calculated by the measured velocity profile, (c) contour of shear rate-temporal $\delta\left(\dot{\gamma}_{\text {eff }}-t\right)$ of montmorillonite dispersion $\left(f_{\mathrm{o}}=1.0 \mathrm{~Hz}, \Theta=4 \pi / 9 \mathrm{rad}\right)$.

している。これは、粘土懸濁液が $\Delta r=O(1 \mathrm{~mm})$ 程 度の遷移層（準ゾル相）を持つことを意味し、市 販レオメータにおける、シェアバンド形成（[2]参 照）の論拠となりえる知見であると考えられる。

\section{2 粒子配列による実効的レオロジー[11]}

Einstein の粘度式[17]、

$$
\eta=\frac{\mu^{*}}{\mu}=1+\frac{5}{2} \varphi
$$

では、完全球形の粒子が分散媒に対し、十分に希 薄な体積率で、かつストークス則を満たすような 条件下にのみ、比粘性が分散粒子の体積率の関数 として示される。シリコンオイル（ニュートン流 体）に密度がほぼ同等な球形粒子（平均直径 0.5 $\mathrm{mm} ; \mathrm{CL}-8007$, 住友精化株式会社) を体積率 $\varphi=$ 0.02 で分散させ、USR による線形粘弾性解析を試 みた（Fig. 5)。左の写真のように、一様分散した 粒子による比粘度は、式(9)とおおよそ同等の值と して見積もることができる。

Einstein の粘度式に端を発し、現代に至るまで 様々な条件 (体積率、粒子形状、粒子径、分散相 の状態等）を考慮した修正式（例えば、[18, 19]）
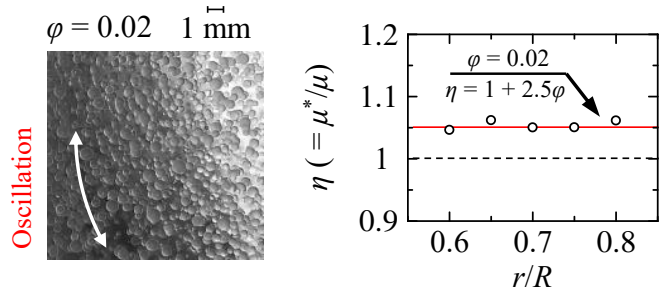

Fig. 5 Photograph taken from the top of the cylinder during oscillations, and radial profile of the relative viscosity $\eta$.
がいくつも提案されているが、どれもニュートン 流体中の分散混相状態が大前提である。

では、非ニュートン流体中に分散する混相体に は、同じことが言えるのだろうか。Scirocco et al. は、異なるワイゼンベルグ数 $(W i=\lambda \dot{\gamma})$ を示す流 体に対して単純せん断を与える調查を行った[20]。 ここで、 $\lambda$ は流体の緩和時間を示し、ニュートン 流体では $\lambda \approx 0$ 、粘弾性流体では $\lambda>0$ という物理 的な意味を持つ。結果として、Wi $>0.5[\lambda>$ $\left.O\left(10^{-2} \mathrm{~s}\right)\right]$ において、一様分散した粒子がせん断方 向に配向する現象が確認された。Lyon et al.は、粘 弾性流体中に分散する粒子がせん断方向に配列 するにつれて、せん断応力として働く、正味の力 は徐々に減少していくことを示した[21]。これら を要するに、粘弾性的性質を有する流体中に分散 する粒子は、せん断変形に対して配向し、実効的 なレオロジー物性を変調させていることが示唆 される。しかしながら、せん断方向に配向するた めに、市販レオメータでは実用的な物性を計測す ることが困難であり、光学可視化撮影等の解析 [22]に留まるのが現状である。

粘弾性を示す、ポリアクリルアミド（PAM）水 溶液 0.5 wt.\%（MTアクアポリマー株式会社）と 前述の $\mathrm{CMC}$ 水溶液 $1.0 \mathrm{wt} . \%$ (株式会社ダイセル) を試験流体として用いた。シリコンオイルと PAM、 CMC を対象に、緩和時間 $\lambda(=\mu / E)$ の円筒半径分 布をUSRにより評価した結果を Fig. 6(a)に示す。 シリコンオイルの場合、全ての半径位置において $\lambda \approx 10^{-3} \mathrm{~s}$ 程度であり、これはニュートン流体の特 徵である短い緩和時間を反映している。PAM の 場合 $\lambda>10^{-1} \mathrm{~s}$ であり、粘弾性的特徵が全半径位 置において確認できる。一方 CMC の場合、先行 


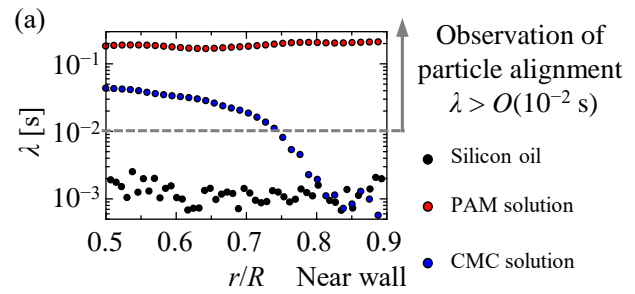

(b)
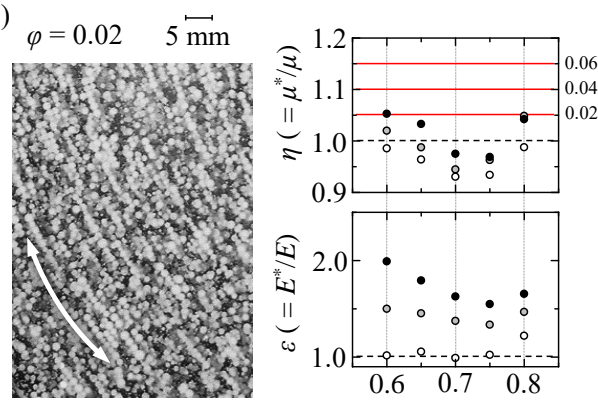

(c)
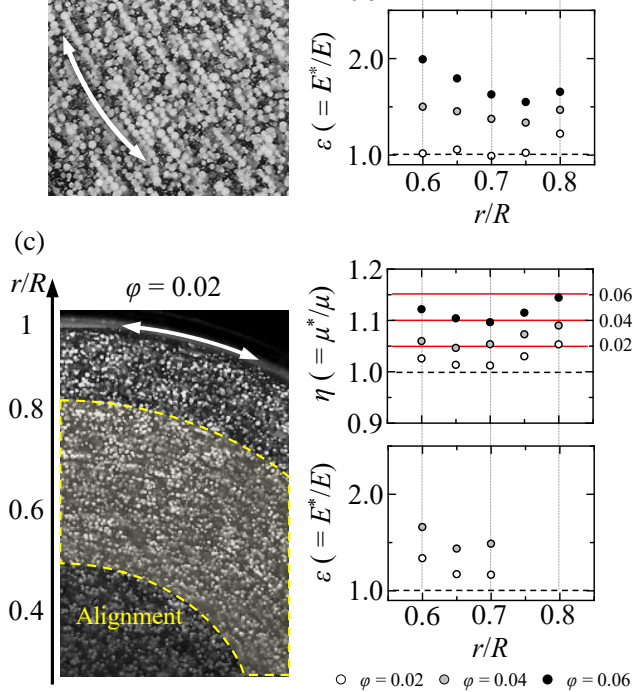

Fig. 6 (a) Radial profiles of relaxation time for different fluids, and photograph taken from the top of the cylinder during oscillations, and radial profile of the relative viscosity $\eta$ and the relative elasticity $\varepsilon$, where the solid line indicates the relative viscosity estimated by $\eta$ $=1+2.5 \varphi$; (b) PAM solution, and (c) CMC solution.

研究[20]における臨界緩和時間を跨ぐように、 $\lambda$ が半径方向に分布を持つ。

$\mathrm{PAM}$ と $\mathrm{CMC}$ 水溶液に等密度の粒子 (平均直径 $0.5 \mathrm{~mm}$; HP20, 三菱厅ミカル株式会社）を体積率 $\varphi$ で分散させ、USRによる粘弾性解析を行い、比 粘性 $\eta$ 、比弾性 $\varepsilon$ を半径区間毎の平均值として評 価した（Fig.6(b), (c))。Fig.6(b)の写真から、PAM 中に分散する粒子はせん断方向に配列を形成し、 $\varphi$ に関わらず比粘性が式(9)で見積もられる值よ り小さい。それに反して、 $\varphi$ が増加するにつれて、 比弾性は増加傾向を示した。一方で、CMC は 半径分布があり、Fig. 6(c) の写真から、 $\lambda>O\left(10^{-2} \mathrm{~s}\right)$ の半径位置で粒子配列が確認できた。さらに、 $\varphi$ が増加するにつれて比粘性は増加し、 $r / R \approx 0.8$ に おいて式(9)とほぼ同值を示した。粒子配列が確認 できる半径位置では、PAM の結果と同様に比粘 性が式(9)より低く、比弾性は増加傾向にあった。

これらの結果から、分散媒の緩和時間は配列形 成に、配列形成は実効的な粘弾性の変調に、との 連鎖的因果関係の存在が示された。PAM による 粒子配列の度合いと CMC を写真から比較すると、 CMC における粒子間隔がより大きいことが定性 的ながら観測できる。同時に、比粘性・比弾性の $\varphi$ の増加に伴う変調度合いも PAM に比べて小さ いが存在する。ゆえに、緩和時間の長短は粒子配 列の度合いに影響を与え、実効的レオロジー物性 を変化させる。この知見は市販レオメータでは見 いだし得ないものであり、USR が新たな見方を与 えた一例といえる。

\section{3 食品のレオロジー計測[13]}

最後に、ハウス食品が販売している「フルーチ エ」を対象にUSR による試験を行った例を紹介 する。フルーチェは、市販されている原液と牛乳 を混ぜるだけで作ることができるデザートで、食 物由来の高分子鎖状構造を持つペクチンがカル シウムイオンと結合・ゲル化することでとろみが 生まれる。その結合は繰り返し剪断を加えること で徐々に崩壊し、ゾル化する。そのため、フルー チェは流動化の意味での降伏、粘弾性、および、 ずり減粘度のレオロジ一的性質を持ち、また分散 体として不定形の果肉を含む。「美味しい食感」 と食品レオロジーの関係は、長年議論されている が、曖昧さは解消されていない。本報告では、混 合する牛乳とフルーチェ原液の質量比を三種類 [(I) Milk : Source=2:1, (II) 1:1, (III) 1:2]設定し、そ れぞれ USR による解析を行った。参考までに、 販売元であるハウス食品では、適切な混合量は原 液 $200 \mathrm{~g}$ に対して牛乳 $200 \mathrm{~mL}$ としている。

Fig. 7(a)-(c)は、各混合比のフルーチェに対し、 簡易的なレオロジー試験結果を示した写真であ る。ガラスシャーレ上に大さじ 1 杯分のフルーチ エを取り出し、水平面に対して 30 度に傾けて約 10 分間放置することで、試験対象のレオロジー特 
Case I (Milk : Source $=2: 1) \quad$ Case II (Milk $:$ Source $=1: 1)$ Case III (Milk : Source $=1: 2)$
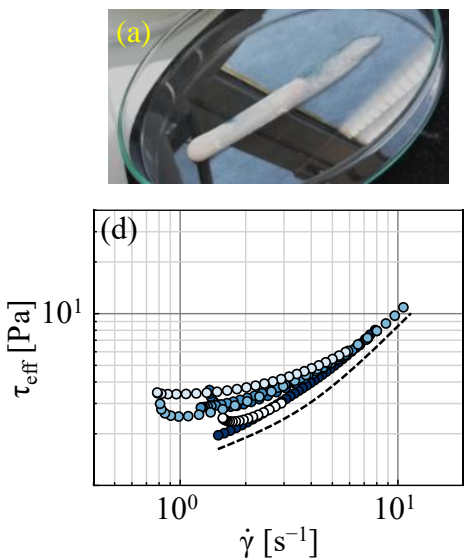
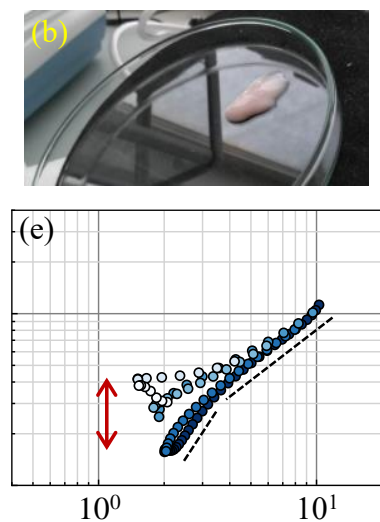

$\dot{\gamma}\left[\mathrm{s}^{-1}\right]$
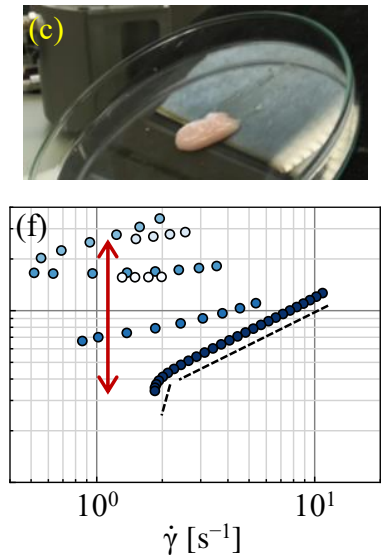

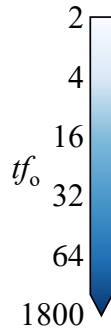

1800

Fig. 7 Photographs of qualitative rheology for test materials prepared by different recipes and placed on 30 degrees inclined glass plates; (a) Milk: Source $=2: 1 \mathrm{mix}$, (b) Milk : Source $=1: 1 \mathrm{mix}$, and (c) Milk : Source = $1: 2$ mix, and transient flow curves ( $\dot{\gamma}_{\text {eff }}-\tau_{\text {eff }}$ ) of the Fruiche with different recipes; (d) Milk : Source $=2$ : $1 \mathrm{mix}$, (e) Milk : Source $=1: 1 \mathrm{mix}$, and (f) Milk : Source $=1: 2$ mix .

性を定性的に調べることができる。Fig. 7(a)より、 牛乳の比率が多い条件では、シャーレ上を容易に 流下寸ることが見て取れる。一方で、Fig.7(b), (c) のように牛乳の質量割合が多い場合、ガラスシャ ーレ上のフルーチェは形状を維持する。特筆す心゙ き点として、フルーチェのガラスシャーレに対す る吸着性の違いが挙げられる。つまり、Fig. 7(b) では、やや下方に変形するのみだが、Fig. 7(c)で は、シャーレ上を滑る特徽も確認できる。

このような特徵を持つフルーチェを対象に、 USR によるレオロジー評価を施し、 $\dot{\gamma}_{\text {eff }}-\tau_{\text {eff }}$ のプ ロットで示す (Fig. 7(d)-(f))。 $\dot{\gamma}_{\text {eff }}-\tau_{\text {eff }}$ が急峻なら ば、物理的には高粘性的な応答を示し、プロット 色の濃淡は振動せん断の周期数を表現している。 条件 I から、振動せん断周期に対し、 $\dot{\gamma}_{\text {eff }}-\tau_{\text {eff }}$ の特 徵は変化せず、緩い曲線形状を示した (Fig. 7(d))。 それに対し、条件 II と III から、振動せん断周期 に対し急激に $\dot{\gamma}_{\mathrm{eff}}-\tau_{\mathrm{eff}}$ が変化し、濃色で示されるプ

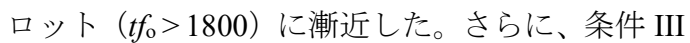
において計算されたせん断応力の変動は、条件 II より顕著であった (Fig.7(e)矢印)。図中点線で示 されるように、最終的な傾向が異なるのも興味深い。

これら USR の結果を踏まえ、定性的なレオロ ジ一的特徵（Fig. 7(a)-(c)）に対して、定量的な考 察を加えることができる。条件 I では、フルーチ エは容易に流下寸る様相を示す。この特徴は、 $\dot{\gamma}_{\mathrm{eff}}$
- $\tau_{\text {eff }}$ における緩やかな曲線形状と合致する。条件 II では、フルーチェはシャーレ上に吸着し、形状 を維持していたが、降伏するせん断ひずみ速度付 近で $\dot{\gamma}_{\mathrm{eff}}-\tau_{\mathrm{eff}}$ が急峻なことから、形状維持に寄与す る物性の存在が定量的に確認できる。条件 III で は、形状を維持しつつも、シャーレ上を滑る特徴 が観測された。これは、振動せん断の初期段階に おいて、降伏に至るせん断速度が $O\left(10^{0} \mathrm{~s}^{-1}\right)$ 以下 まで減少することに由来すると推論できる。
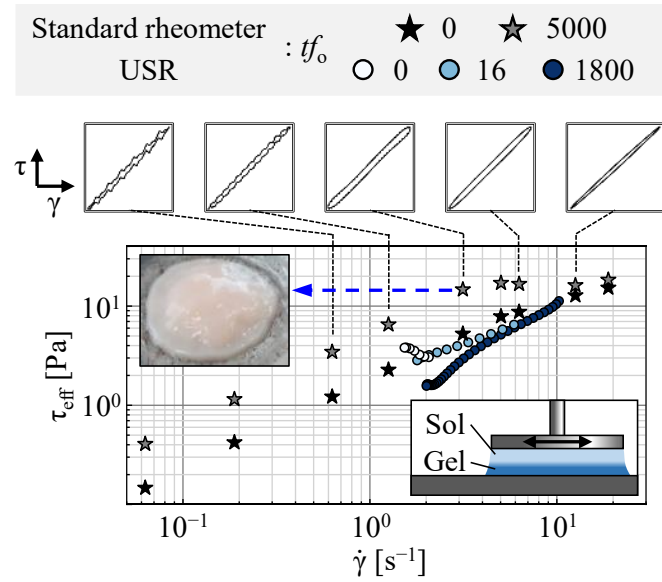

Fig. 8 Flow curves $\left(\dot{\gamma_{\text {eff }}}-\tau_{\text {eff }}\right)$ of the test material (Milk : Source $=1: 1 \mathrm{mix}$ ) in oscillatory test of commercially-supplied rheometer plotted with USR results. 
USR を市販レオメータの振動せん断試験と比 較することで、データの優位性・実用性について 議論する。用いるのは Large amplitude oscillatory shear 試験なる方法[4]で、シェアバンド等の現象 を非線形粘弾性応答により評価する方法である。 結果をそれぞれ Fig. 8 に示す。星形は、市販レオ メータを用いた振動せん断試験によって評価さ れた $\dot{\gamma}_{\text {eff }}-\tau_{\text {eff }}$ の関係を示している。Fig. 8 中の丸形 はFig. 7(e)の結果と同様である。星形における $t f_{0}$ $=0$ は、 $\dot{\gamma}=200 \mathrm{~s}^{-1}$ の定常回転を与えた後、振動せ ん断試験を開始した直後の結果を示す。図中星形 から、 $\dot{\gamma}<10^{1} \mathrm{~s}^{-1}$ で時間経過とともに、せん断応力 が増加していることがわかる。文献[23]で指摘さ れるように、時間とともに物性が変動する対象を レオメータで計測する場合、その解釈は容易では ない。Fig. 8 上部に示したリサージュ図から、振 動一周期内におけるせん断応力とひずみの変動 度合いを読みとれる。USRによって得られた降伏 ひずみ速度以下で、そのリサージュ図には細かい ゆがみが確認された。さらに、レオメータにおけ る長時間計測後のサンプルを観測すると、Fig. 8 の写真のように変形する層と変形しない層に分 離していた (Fig. 8 右下)。動的レオロジー評価を 行う上で、振動せん断変形は最も一般的だが、市 販レオメータにおける長時間計測（終端状態）が レオロジー物性を表現する上で「実用的」かどう かは、必ずしも断言できない。

\section{4. 結 論}

本稿では、チキソトロピー性流体の時空間レオ ロジー評価、流体緩和時間に起因する粒子配列が 引き起こす実効粘弾性変調、並びに美味しさを評 価するための実用的な評価など、USR を用いた混 相流体のレオロジー試験例を紹介した。これら試 験例では、市販レオメータの計測確度が保証され 難い対象をあえて選択した。当然、我々の提案す る USR にも守備範囲外は存在し、 $O\left(10^{3} \mathrm{~Pa}\right)$ 以上 の高粘性流体や、 $O\left(10^{-3} \mathrm{~Pa}\right.$ s $)$ 以下の極低粘性流体、 準完全弾性体などが例示できる。それらは市販レ オメータで高精度のレオロジー物性計測がすで に可能とされている計測対象である。つまり、 USR と市販レオメータとの間には、互いの適用範 囲外の計測対象を相互に補い得る、相補的な使用 が見込まれる。

弾塑性理論から発展を遂げた市販レオメータ の原理に対して、流体力学的視点を取り入れた

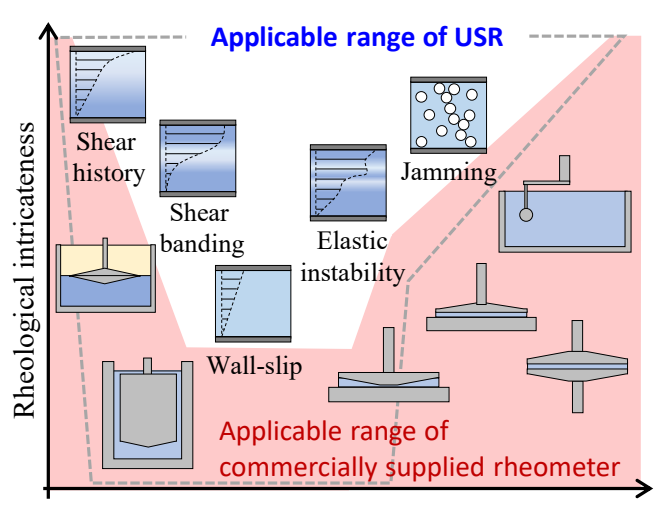

Apparent viscosity of test fluid

Fig. 9 Schematic diagram of the expected applicable range in commercially supplied rheometer and USR.

USR を提案した。本研究を足掛かりとして、数世 紀にわたる市販レオメータの課題が解決される 契機となれば幸いである。

\section{謝 辞}

研究を遂行するにあたり、助言ならびにレオメ 一タの指導をいただいた、広島大学の並木敦子先 生、モンモリロナイトに関する技術指導をいただ いた、電力中央研究所の田中真悟先生、食品レオ ロジー計測・評価・考察に際し、ご協力いただい たスイス連邦工科大学チューリッヒ校の Prof. Dr. Peter Fischer に感謝する。本報で紹介した内容は、 基盤研究(B)No.19H02057、学術振興会特別研究員 研究奨励費 No.18J20516、および学術振興会の若 手研究者海外挑戦プログラムによる支援を含ん でいる。

\section{Nomenclature}

E : elasticity

[Pa]

$E^{*} \quad$ : effective elasticity

$[\mathrm{Pa}]$

$f_{\mathrm{o}} \quad$ : oscillation frequency

$\left[\mathrm{s}^{-1}\right]$

$F_{\text {cost }} \quad:$ cost function

$r \quad$ : radial position

$R \quad:$ cylinder radius

$\left[\mathrm{N} \mathrm{m}^{-1}\right.$ ]

$t \quad$ : elapsed time

$[\mathrm{m}]$

[m]

$T$ : fluid temperature

[s]

$\left[{ }^{\circ} \mathrm{C}\right]$

$u \quad$ : azimuthal velocity

$\left[\mathrm{m} \mathrm{s}^{-1}\right]$

$u_{\xi} \quad$ : measured velocity

$\left[\mathrm{m} \mathrm{s}^{-1}\right]$

$U_{\text {wall }} \quad$ oscillating wall velocity

$\left[\mathrm{m} \mathrm{s}^{-1}\right]$

Wi : Weissenberg number 


\section{Greek letters}

$\Delta y \quad$ : off-axis displacement from cylinder [m]

$\dot{\gamma} \quad$ : shear strain rate $\quad\left[\mathrm{s}^{-1}\right]$

$\dot{\gamma}_{\text {eff }}:$ effective shear strain rate $\quad\left[\mathrm{s}^{-1}\right]$

$\delta \quad$ : phase lag [rad]

$\varepsilon \quad:$ relative elasticity $\quad[-]$

$\eta \quad$ : relative viscosity $\quad[-]$

$\Theta \quad$ : oscillating angle of cylindrical vessel $\quad[\mathrm{rad}]$

$\lambda \quad$ : relaxation time

$\mu \quad$ : viscosity

$\mu^{*} \quad$ : effective viscosity

$\xi \quad:$ distance from transducer

$\rho \quad:$ density

$\tau \quad:$ shear stress

$\tau_{\text {eff }} \quad$ : effective shear stress

$\varphi \quad$ : volume fraction

$\phi \quad$ : Phase lag of velocity fluctuation

$\omega_{0}:$ oscillation angular frequency

[Pa s]

[Pa s]

[m]

$\left[\mathrm{kg} \mathrm{m}^{-3}\right]$

$[\mathrm{Pa}]$

$[\mathrm{Pa}]$

$[-]$

[rad]

$\left[\mathrm{rad} \mathrm{s}^{-1}\right]$

\section{参考文献}

[1] Yang, K. and Yu, W., Dynamic Wall Slip Behavior of Yield Stress Fluids Under Large Amplitude Oscillatory Shear, J. Rheol. Vol. 61(4), 627-641 (2017).

[2] Divoux, T., Fardin, M. A., Manneville, S. and Lerouge, S., Shear Banding of Complex Fluids, Annu. Rev. Fluid Mech., Vol. 48, 81-103 (2016).

[3] Fischer, P., Wheeler, E. K. and Fuller, G. G., Shear-banding Structure Orientated in the Vorticity Direction Observed for Equimolar Micellar Solution, Rheol. Acta, Vol. 41, 35-44 (2002).

[4] Perge, C., Taberlet, N., Gibaud, T. and Manneville, S., Time Dependence in Large Amplitude Oscillatory Shear: A Rheo-ultrasonic Study of Fatigue Dynamics in a Colloidal Gel, J. Rheol., Vol. 58, 1331-1357 (2014).

[5] Carotenuto, C. and Minale, M., On the Use of Rough Geometries in Rheometry, J. Non-Newton. Fluid Mech. Vol. 198, 39-47 (2013).

[6] Ancey, C., Solving the Couette Inverse Problem Using a Waveletvaguelette Decomposition, J. Rheol. Vol. 49, 441-460 (2005).

[7] Tasaka, Y., Kimura, T. and Murai, Y., Estimating the Effective Viscosity of Bubble Suspensions in Oscillatory Shear Flows by Means of Ultrasonic Spinning Rheometry, Exp. Fluids, Vol. 56, 1867 (2015).

[8] Yoshida, T., Tasaka, Y. and Murai, Y., Rheological Evaluation of Complex Fluids Using Ultrasonic Spinning Rheometry in an Open Container, J. Rheol., Vol. 61(3), 537-549 (2017).

[9] Tasaka, Y., Yoshida, T., Rapberger, R. and Murai, Y., Linear Viscoelastic Analysis Using
Frequency-domain Algorithm on Oscillating Circular Shear Flows for Bubble Suspensions, Rheol. Acta, Vol. 57(3), 229-240 (2018).

[10] Yoshida, T., Tasaka, Y., Tanaka, S., Park, H. J. and Murai, Y., Rheological Properties of Montmorillonite Dispersions in Dilute $\mathrm{NaCl}$ Concentration Investigated by Ultrasonic Spinning Rheometry, Appl. Clay Sci., Vol. 161, 513-523 (2018).

[11] Yoshida, T., Tasaka, Y. and Murai, Y., Efficacy Assessments in Ultrasonic Spinning Rheometry: Linear Viscoelastic Analysis on Non-Newtonian Fluids, J. Rheol., Vol. 63(4), 503-517 (2019).

[12] Yoshida, T., Tasaka, Y. and Murai, Y., Effective Viscoelasticity of Non-Newtonian Fluids Modulated by Large Spherical Particles Aligned Under Unsteady Shear, Phys. Fluids, Vol. 31(10), 103304 (2019).

[13] Yoshida, T., Tasaka, Y. and Fischer, P., Ultrasonic Spinning Rheometry Test on Rheology of Gelled Food for Making Better Tasting Desserts, Phys. Fluids, Vol. 31(11), 113101 (2019).

[14] Ouriev, B. and Windhab, E. J., Transient Flow of Highly Concentrated Suspensions Investigated Using the Ultrasound Velocity Profiler-Pressure Difference Method, Meas. Sci. Technol., Vol. 14, 1963-1972 (2003).

[15] Murai, Y., In: Y. Takeda (ed.) Ultrasonic Doppler Velocity Profiler for Fluid Flow, Vol. 101, Springer, Tokyo, 153-156 (2012).

[16] Coussot, P., Structural Similarity and Transition from Newtonian to Non-Newtonian Behavior for Clay-Water Suspensions, Phys. Rev. Lett., Vol. 74(20), 3971-3974 (1995).

[17] Einstein, A., Eine neue Bestimung der Molekuldimensionen, Ann. Phys., Vol. 19, 289306 (1906).

[18] Mooney, M., The Viscosity of a Concentrated Suspension of Spherical Particles, J. Colloid Sci., Vol. 6, 162-170 (1951).

[19] Frankel, N. A. and Acrivos, A., On the Viscosity of a Concentrated Suspension of Solid Spheres, Chem. Eng. Sci., Vol. 22, 847-853 (1967).

[20] Scirocco, R., Vermant, J. and Mewis, J., Effect of the Viscoelasticity of the Suspending Fluid on Structure Formation in Suspensions, J. NonNewton. Fluid Mech., Vol. 117, 183-192 (2004).

[21] Lyon, M. K., Mead, D. W., Elliott, R. E. and Leal, L. G., Structure Formation in Moderately Concentrated Viscoelastic Suspensions in Simple Shear Flow, J. Rheol., Vol. 45, 881-890 (2001).

[22] Won, D. and Kim, C., Alignment and Aggregation of Spherical Particles in Viscoelastic Fluid Under Shear Flow, J. Non-Newton. Fluid Mech. 117, 141-146 (2004).

[23] Barnes, H. A., Thixotropy -a Review, J. NonNewton. Fluid Mech. 70, 1-33 (1997). 